\title{
The perceived impact of the group practice model on enhancing interpersonal skills of predoctoral dental students
}

This article was published in the following Dove Press journal: Journal of Healthcare Leadership

\author{
Margaret R Errante' \\ Gurjinder S Gill2 \\ Tobias E Rodriguez ${ }^{3}$ \\ 'Business Development, Dental \\ Health Center, Boston University \\ Henry M. Goldman School of \\ Dental Medicine, Boston, MA, USA; \\ ${ }^{2}$ Business and Strategic Planning and \\ Implementation, Boston University \\ Henry M. Goldman School of Dental \\ Medicine, Boston, MA, USA; ${ }^{3}$ Academy \\ for Academic Leadership, Atlanta, GA, \\ USA
}

Correspondence: Margaret R Errante Business Development, Dental Health Center, Boston University Henry M. Goldman School of Dental Medicine, 100 E Newton Street, Boston, MA 02I I8, USA

Tel + I 6176384743

Email merrante@bu.edu
Purpose: The purpose of this study was to assess if a clinical group practice model has an impact on enhancing the interpersonal skills of predoctoral dental students, what factors may influence the development of these skills, and what, if any, are innovative and technological solutions that can potentially influence interpersonal skills in predoctoral dental students.

Methods: This study surveyed the faculty responsible for teaching the dental students in a recently developed group practice model. Out of 18 eligible group practice leaders at one US dental school, 17 respondents $(94.4 \%)$ completed the survey. In addition, this study asked the faculty to provide qualitative response and recommendations to improve interpersonal skills. Based on the feedback, a focus group was conducted to explore opportunities to further enhance the skills.

Results: The results of the study suggest that the group practice model has a positive and distinct impact on the development of overall interpersonal skills for students. Further research suggests that the greatest impacted areas of personal development are critical thinking skills and teamwork. However, as a way to make the model more effectual, most faculty suggested the need for additional time, for both students and faculty. To some extent, using technology and innovative teaching pedagogies could potentially address the challenge of limited time.

Conclusion: Based on the results of the survey, one may conclude that with adequate design and conditions, the group practice model can have a positive effect on the interpersonal skills of its students.

Keywords: interpersonal skills, teamwork, critical thinking, group practice model, dental education, innovative solutions

\section{Introduction}

Interpersonal skills are sometimes described as soft skills, or a type of emotional intelligence. The skills most commonly considered in this category are communication, critical thinking and problem-solving, leadership, teamwork, professional ethics, lifelong learning, and innovation. ${ }^{1,2}$ Strong interpersonal skills are among the top criteria used to evaluate candidates when employers are hiring. Having this skill set often differentiates an average candidate from an outstanding clinician. ${ }^{3}$ However, interpersonal skills go beyond employment. Professional success, personal fulfillment, and responsible citizenship require a set of skills necessary in a complex world and working environment. Interpersonal skills provide an individual with an ability to understand and analyze problems contextually and critically, and address them creatively and holistically. 
One of the challenges in assessing interpersonal skills is that skill sets are usually measured collectively, rather than individually, via a questionnaire or survey. It is difficult to distinguish clearly between specific social skills and personality traits, knowledge, and cognitive processes, possibly influenced by previous experiences. In addition, while completing a survey, a respondent may find it difficult to distinguish between related skills such as teamwork and collaboration. As a result, the outcomes of these assessments do not provide clear definitions of a specific skill for each respondent. Rather, these assessments provide a holistic overview of all the skills, making analysis and intervention difficult. ${ }^{4}$ The existing definitions of interpersonal skills were developed in the context of interactions that primarily occur face to face, but new technologies foster interactions that do not occur face to face or in a single window of time.

These distinctions are important to note when examining the interactions among different facets of interpersonal skills. Furthermore, direct observation of individual and team interactions offers its own measurement and interpretation challenges. Additionally, there is very little documentation about which interpersonal skills are most effective, which are most critical for success, and how to develop these skills. ${ }^{5}$ There are various tests and projects that attempt, and/or claim, to enhance these skills. Some even suggest that role-playing and simulation work help to reinforce interpersonal skills. ${ }^{6}$ However, no one contests that with an increasing number of new dental graduates employed by large group practices, these skills are becoming more vital for the success of both employee and employer.

Tasked with developing students into competent general dentists, the primary focus of education in dental schools is in biomedical science knowledge and clinical skills, with very little time left for the professional development of students. Studies show that US dental schools typically teach interpersonal skills in didactic courses rather than in clinical scenarios where there is patient interaction and evaluation. ${ }^{7}$

Strong interpersonal skills have long been considered essential and critical for the dentist-patient relationship. Most of the emphasis on dentist-patient relationship is the ability of the dentist to create a rapport with the patient. A good relationship is beneficial for both the dentist and the patient. It helps to create increased patient compliance, loyalty, better therapeutic results, and reduced anxiety for the patient. ${ }^{8,9}$ Most of the skills necessary for this relationship are developed in the clinical setting. Frequently, students learn by observing the supervising faculty during patient interactions.
As expected, some faculty members are better at these interactions than others. Since this is a critical relationship between dentist and patient, most schools create a focus on the importance of this relationship for the success of the dentist. ${ }^{10}$ While many US dental schools use a group practice model to educate predoctoral students, relatively little has been published on the model's influence on interpersonal skills. The group practice model places the dental students in groups with group practice leaders (GPLs) who are available to instruct, evaluate, and advise the students regarding comprehensive patient care and chair-side instruction in diagnosis and treatment planning.

Recently, the American Dental Association has noted shifts in patterns of dental care. First, prior to the 2008 recession, adult dental expenditures experienced a decrease (expected to remain flat). ${ }^{11}$ Second, the care for an adult population has become much more consumer focused. Consumers ask more questions and are more actively involved in their care. With these changes, interpersonal skills such as communication need to be heightened in order for the practicing dentist to be competitive.

There have also been significant changes with new dentists entering the workforce. ${ }^{12}$ Work patterns are changing with women reaching $50 \%$ of the graduating class. Many women choose to work part time at the start of their career. ${ }^{11}$ Of those working part time, many choose employment with a dental practice. In addition, student debt has reached record highs. ${ }^{13}$ With significant student debt, new graduates are contemplating different work arrangements. ${ }^{14}$ It is imperative for students with high debt to start earning income immediately and have an immediate patient base to treat. These factors have contributed to an increase in new graduates employed in group practice settings. Many group practices have multiple locations, multiple clinicians in one location, and the possibility of dental specialists working side by side with general dentists in delivering care to a shared patient.

With the structure of group practices, the dentist interacts with a larger circle of people on a daily basis. In addition to all of these possible encounters, the dentist in a group practice interacts with administrative management, other medical professionals, and dental laboratory professionals. Moreover, with social media, interactions have grown exponentially and become more sophisticated and complex.

The Commission on Dental Accreditation (CODA) adjusted the standards for dental school accreditation in response to the changing scope of practice, including an emphasis on interpersonal skill development. ${ }^{15}$ While CODA has outlined standards specific to identified skills 
(eg, comprehensive patient-centered care, critical thinking, humanistic environment, diversity, and collaboration with other health care providers), each dental program can implement and assess these skills as they see best. ${ }^{15}$ Similarly, the Association of American Medical Colleges has supported Entrustable Professional Activities (EPAs) to measure if a medical school graduate is competent to enter a residency. EPAs are units of professional practice, defined as tasks or responsibilities that trainees are entrusted to perform unsupervised once they have attained sufficient specific competence. ${ }^{16}$ These core EPAs incorporate many elements of interprofessional communication skills in addition to technical skills. ${ }^{16,17}$

In response to the changes noted earlier and the desire to create the best experience possible for the predoctoral dental students and patients at the Boston University Henry M. Goldman School of Dental Medicine (GSDM), GSDM made a transition in 2014 to develop a group practice model for predoctoral students. Substantial financial and human resource commitments made this undertaking possible. The overall practice model comprised nine individual group practices; each group practice has two GPLs, for a total of 18 GPLs. Having two GPLs per group guarantees that each group of students will have a GPL available at all times that the clinic is open. The GPLs are responsible for leading a clinical practice of $\sim 14$ third-year students and 21 fourth-year students. The GPLs act as role models teaching the skills of ethics, patient relationship management, respect, professionalism, and "how to think like a dentist".

The Group Practice Leadership Program at GSDM supports "Vertically Integrated Teams within Group Practices". Each Group Practice has designated spaces, staff, faculty, predoctoral students, and postdoctoral residents. The intention of the Group Practice model at the GSDM is to create "continuity of care for (our) patients within a patient-centered clinical education construct for faculty-guided, student provided, high quality oral health care".

The role of the GPL is focused on teaching interpersonal skills, clinical instruction, and managing his or her groups' patient care based on best practices of a general dental practice. The GPL position requires 5-10 years of substantial experience in private dental practice or dental education. The GPLs must demonstrate a passion for dentistry and have a strong desire to teach. They must exhibit excellent time management skills, be collaborative and cooperative, and demonstrate common sense. They must have a commitment to lifelong learning and have excellent oral and written communication skills. They must display a strong business acumen and organizational awareness. The job description has a strong emphasis placed on interpersonal skills of the GPLs.

This research investigates the perceived impact of the group practice model on enhancing interpersonal skills of predoctoral students, in addition to improving the experience for the students and patients. The idea for this research came about based on the following (as previously discussed): interpersonal skills are considered essential in being a successful employee; the researchers performing this study understand this and work to deliver employable dentists, but recognize that interpersonal skills are not always taught in the most appropriate setting. It seems logical to have interpersonal skills taught in a group practice. Having a group practice in place, the researchers are testing their theory by evaluating the perceived impact of the group practice model on enhancing interpersonal skills within predoctoral students via surveys, in the hope that the findings will be useful. Future research is needed to justify this perception and hopefully create awareness in dental schools of the most logical location (group practice) to enhance interpersonal skills.

\section{Materials and methods}

The Institutional Review Boards at the University of the Pacific and at Boston University reviewed and approved the research protocol described in this article as exempted research. Based on Department of Health and Human Services policy regarding protection of human subjects, this project falls in exemption category \#1. The research project consisted of a mixed method survey of a volunteer group of GPLs (faculty) at GSDM. Subjects' opinions were gathered in response to a questionnaire about interpersonal skills training as a reflection of the group practice model in the clinic. The data were stored on a computer by code number so that there was no way that an individual name could be associated with specific responses. For purposes of contacting the subjects, there was a separate list of email contacts without corresponding code numbers that enabled distribution of the survey. The master code list was destroyed upon completion of the project. All subjects were volunteers and were free to drop out of the research at any time with no penalty or loss of benefits. The survey (Figure S1) was nonsensitive in nature. Over a period of 3 weeks, the GPLs at GSDM were surveyed to determine if the group practice model has any impact on the development of interpersonal skills of predoctoral students.

Prior to receiving the surveys, an initial meeting was held with 18 GPLs to describe the research that would be conducted. All 18 GPLs agreed to being involved, and a 
survey was disseminated through Qualtrics, an electronic survey program. Completion of the survey was deemed to be informed consent.

Participation in the survey was anonymous and the only identifying data recorded were gender, number of years since graduation from dental school, and number of years as a faculty member at a dental school. The participants were given 3 weeks to complete the survey. Seventeen out of the 18 GPLs at the GSDM submitted completed surveys and the surveyed population represents $94 \%$ of the GPLs at the dental school. The faculty was asked to answer two surveys - first on the impact of the group practice model enhancing interpersonal skills and second to rank the importance of eight interpersonal defining skills measured on a 5-point Likert-style scale. Those conducting this study used descriptive statistics to discuss the perceived impact of the group practice model on each interpersonal skill. The survey results are tabulated and formatted into tables and graphs, and are described in the following section.

Table 1 shows the demographic information of the surveyed population. The majority of the surveyed population was male (65\%). Most of the surveyed GPLs had worked as faculty members for $<10$ years. The majority graduated $\geq 20$ years ago. Participants in the survey were asked about demographic information, the overall impact of the group practice model, how the model affected specific interpersonal skills, and they were allowed the opportunity to provide qualitative feedback. Based on the feedback from the survey, a follow-up

Table I Years since your graduation from dental school, years as a faculty member, and demographic information

\begin{tabular}{|c|c|c|c|c|}
\hline Question & Answer & Response & $\%$ & \begin{tabular}{|l} 
Total, \\
$\%$
\end{tabular} \\
\hline \multirow{3}{*}{$\begin{array}{l}\text { Years since your } \\
\text { graduation from dental } \\
\text { school }\end{array}$} & $0-10$ years & I & 6 & \multirow[t]{3}{*}{100} \\
\hline & $\mathrm{II}-20$ years & 7 & $4 I$ & \\
\hline & $21+$ years & 9 & 53 & \\
\hline \multirow[t]{3}{*}{ Years as a faculty member } & $0-10$ years & 12 & 71 & \multirow[t]{3}{*}{100} \\
\hline & $\mathrm{II}-20$ years & 3 & 18 & \\
\hline & $21+$ years & 2 & 12 & \\
\hline \multirow[t]{2}{*}{ Demographic } & Male & II & 65 & \multirow[t]{2}{*}{100} \\
\hline & Female & 6 & 35 & \\
\hline
\end{tabular}

focus group was conducted to explore innovative solutions to make the group practice model more effective. The focus group, attended by six GPLs (33\%), was presented with the findings from the survey, and then asked to provide additional feedback and insight into the data.

\section{Results}

Based on the participants' ratings, the group practice model is believed to have a significant impact ( $76 \%$ of respondents chose "strongly impacts" and the remainder chose "impacts") on development of students' interpersonal skills. The weighted mean of $4.765 \pm 0.08$ (out of 5) along with an SD of 0.35 statistically indicates the compactness and relevance of the data results. Table 2 displays the results of a qualitative rating scale representing the GPLs' perceived view on the influence of the model on development of interpersonal skills as a whole.

Furthermore, in terms of the greatest impacted area (highlighted in Table 3) of predoctoral personal development, the participants rated teamwork $(6.12 \pm 0.47)$, critical thinking skills (6.00 \pm 0.56$)$, and verbal and nonverbal listening skills (5.24 \pm 0.47$)$ as most influenced. The least impacted aspect was leadership $(2.24 \pm 0.41)$ as the area of personal development. The other two attributes that ranked low were assertiveness and negotiation skills. Table 3 displays the results, in ranking order ( 8 being most influenced and 1 least), of further exploration of eight attributes that constitute interpersonal skills.

The responses in Box 1 indicate that participants felt that an increase in available time between GPLs and students could be one of the most valuable additions to have a direct impact on enhancing interpersonal skills.

On further brainstorming possible solutions to address the challenge of time, the common theme was to explore innovative teaching methodologies that resonated with this generation of students and made available as an adjunct or elective to overcome the challenge of limited time. A skill set could be introduced by offering an online micro-course highlighting its application in different scenarios for a student to review before a class or clinical session and have a discussion

Table 2 Factors perceived to be impacted by the group practice model

\begin{tabular}{|l|l|l|l|l|l|l|l|l|l|}
\hline & $\begin{array}{l}\text { Strongly } \\
\text { impacts }\end{array}$ & Impacts & Neutral & $\begin{array}{l}\text { Does not } \\
\text { impact }\end{array}$ & $\begin{array}{l}\text { Strongly does } \\
\text { not impact }\end{array}$ & $\begin{array}{l}\text { Total } \\
\text { responses }\end{array}$ & Mean & SD \\
\cline { 2 - 9 } & $\mathbf{5}$ & $\mathbf{4}$ & $\mathbf{3}$ & $\mathbf{2}$ & $\mathbf{I}$ & SE \\
\hline $\begin{array}{l}\text { Overall development of } \\
\text { interpersonal skills }\end{array}$ & 13 & 4 & 0 & 0 & 0 & 17 & 4.765 & 0.35186578 & 0.08534 \\
\hline
\end{tabular}

Abbreviation: SE, Standard error. 
Table 3 Skill sets believed to be most influenced directly by the group practice model

\begin{tabular}{|c|c|c|c|c|c|c|c|c|c|c|c|}
\hline \multirow[t]{2}{*}{ Skill set } & \multirow{2}{*}{\begin{tabular}{|l|}
$\begin{array}{l}\text { Most } \\
\text { influenced }\end{array}$ \\
8 \\
\end{tabular}} & \multicolumn{6}{|c|}{$\longrightarrow$} & \multirow{2}{*}{\begin{tabular}{|l|}
$\begin{array}{l}\text { Least } \\
\text { influenced }\end{array}$ \\
$I$ \\
\end{tabular}} & \multirow[t]{2}{*}{$\begin{array}{l}\text { Weighted } \\
\text { average }\end{array}$} & \multirow[t]{2}{*}{ SD } & \multirow[t]{2}{*}{ SE } \\
\hline & & 7 & 6 & 5 & 4 & 3 & 2 & & & & \\
\hline $\begin{array}{l}\text { Verbal, nonverbal, and } \\
\text { listening skills }\end{array}$ & 2 & 3 & 33 & 3 & 33 & 2 & 0 & 1 & 5.24 & 1.92 & 0.47 \\
\hline Critical thinking skills & 7 & 2 & 1 & 4 & 0 & 1 & 1 & 1 & 6.00 & 2.29 & 0.56 \\
\hline Negotiation skills & 1 & 0 & 0 & 2 & 6 & 3 & 4 & 1 & 3.53 & 1.62 & 0.39 \\
\hline Collaboration & $\mathrm{I}$ & 4 & 3 & 2 & 3 & I & $\mathrm{I}$ & 2 & 4.88 & 2.18 & 0.53 \\
\hline Assertiveness & 0 & 2 & 0 & $\mathrm{I}$ & 2 & 4 & 5 & 3 & 3.06 & 1.85 & 0.45 \\
\hline Self-reflection & 0 & 3 & 6 & 3 & 1 & I & 2 & 1 & 4.94 & 1.89 & 0.46 \\
\hline Teamwork & 6 & 2 & 4 & I & 2 & I & I & 0 & 6.12 & 1.93 & 0.47 \\
\hline Leadership & 0 & 1 & 0 & 1 & 0 & 4 & 3 & 8 & 2.24 & 1.68 & 0.41 \\
\hline Total & 17 & 17 & 17 & 17 & 17 & 17 & 17 & 17 & & & \\
\hline
\end{tabular}

Abbreviation: SE, Standard error.

Box I Qualitative responses to improve the impact on teaching interpersonal skills

\begin{tabular}{l} 
- Academic time. \\
\hline - More time to spend with group as a whole. More time to spend one on one. \\
\hline - Time for the group leaders to be with the students. We used to spend considerable time in pretreatment planning visits and discussing upcoming \\
treatment. During these visits, we had wonderful opportunities to model and impact our students' interpersonal skills. For a number of reasons \\
(most without factual basis), this time was determined by administration to be making it more difficult for our students to get to clinic and treat \\
patients quickly. The pre-meeting process was discontinued and our students have suffered. \\
\hline - Time for pretreatment plan discussions, particularly for complicated cases (Type II). \\
\hline - New, structured curriculum focused on doctor-patient relationship, communication, empathy, case presentation, problem management. \\
\hline - Role-playing with standardized patients prior to entering the clinic. Additionally, I personally believe that lectures outside of the dental zone, for \\
example theater classes and interrelationship classes, could help with interpersonal skills. \\
\hline - Mutual respect to each other, including students, patients, staff, and faculties. \\
\hline - More dedicated time for GPLs to spend one on one with students. Often times GPLs have additional responsibilities that prevent us from giving \\
the students the one on one mentoring that we can. \\
- More vertical integration between classes. \\
\hline - I think junior and senior students paired and working together within the group could provide valuable learning experiences. \\
\hline - I would say the main thing that could impact interpersonal skills would be time spent directly with the students. \\
\hline - The students need to realize the most effective way to develop rapport with patients is to engage them in conversation while they are sitting in \\
the dental chairs rather than by phone, email, text, etc. \\
\hline - More knowledge on marketing strategy in everyday practice. \\
\hline - Financial support system where patients will be able to pay for treatment and students able to have more experience. \\
- Evaluation and reevaluation of treatment planning process.
\end{tabular}

Abbreviation: GPL, group practice leaders.

on it. This could potentially address the challenge of time and create a consistent foundation before being exposed to different styles of GPLs. Responses from the focus group are summarized in Box 2.

\section{Discussion}

This study was aimed to ascertain the perceived importance of the group practice model in developing students' interpersonal skills and to identify the relative importance of the attributes constituting those skill sets. The structure and design of the group practice model are believed to have positively affected the interpersonal development of the predoctoral students. The primary intention of the model is to stimulate the operations of group dental practice. This type of simulated learning is valuable as it allows students to gain hands-on understanding of clinical procedures in addition to the didactic instruction they receive. The interactive learning allows students not only to gain understanding of how a group dental practice is structured, but also gives students an opportunity to improve a number of interpersonal skills. For example, the students can perform role-play between themselves and their GPLs to practice speaking to patients about sensitive or difficult matters, such as a failed dental procedure. Additionally, students can learn how to conduct themselves appropriately in dentist-patient interactions through observing the behaviors of their GPLs. Students, 
Box 2 Qualitative responses to explore innovative teaching methodologies

- The current generation of dental students is accustomed to using short blurbs of the digital age.

- Ways to enhance these skills, by using different scenarios to show the students in a short video form or other technological ways.

- At some level, it is counterintuitive to teach interpersonal skills in a non-interpersonal setting (online)

- As in every setting, everyone has different skill sets, so when the DMD students are assigned to one particular GPL, they may be striving in one skill set that the GPL is exceptional in, and lacking in other fields, which is essentially hurting the overall skill sets necessary to become successful dentists. It is suggested that there needs to be some way to generalize what they are getting, and to be able to give all of the students a similar kind of experience and to create a course that might offer fundamentals online could be helpful.

- It was suggested again that small videos focusing on different procedures, role model situation, professionalism, etc [...] would be beneficial for the students depending on the situation.

- It was discussed with the group about development of a program across the country; 8-10 students would work together as a team addressing different situations in an office. In this case, the students would work together in a hypothetical office and given a patient base. The students would determine what inventory they would need for the week's procedures, what procedure they would choose per case, deal with insurance questions, and whether or not the office should take the insurance, etc [...]. At the end of the week, an administrator would send results of what would happen to the clinic based on their choices throughout the week, for example: financially, practice management, and much more. This would show how to manage different situations and problems that arise and indicate the impact on the office per decision made. It was further suggested that in the simulation, faculty who is responsible for communication within the group practice, could rate the students throughout the week linking to the simulation, and at the end of each week the communication piece monitored in clinic would be a part of the results for the virtual simulation.

- It was suggested that interactive webinars, specifically interpersonal skills, are a way to reach students. Further suggested a webinar, where based on the students' response, the scenarios change.

- It was suggested that technology can help; the students who struggle can go back (even after graduation) and review the videos provided to help them further understand the procedure that needs to be completed. This technology would essentially help the student succeed in the long term.

- One GPL suggested podcasts or webinars, since this generation is interested more into multimedia instead of needing to be at a set location, which would be easy to access.

Abbreviations: DMD, Doctor of Medicine in Dentistry; GPL, group practice leader.

as of late, have been more inclined to maintain contact with patients via text and email, and GPLs can help students become more comfortable with personal modes of interface. A key component to the success and efficiency of the group practice model is a strong mentor-mentee relationship between the GPLs and predoctoral students. As evident in the results of the survey, time is essential to allow the students and leaders to develop that necessary relationship.

Teamwork is the top skill influenced by the group practice model (Table 2) and one of the most important skills to have when working within a practice. ${ }^{18}$ The ability to work within a team is something employers highly regard when hiring. Practices benefit greatly when employees work together to accomplish goals. Critical thinking is also in the top three skill sets most influenced by the group practice model (Table 2). Critical thinking skills allow the students to contribute their own ideas in the practice. The students must possess the ability to think rationally and use evaluation of evidence to guide decisions regarding patient care. Based on the data (Table 2), verbal and nonverbal listening skills are third on the list of importance. When looking at the characteristics that build a strong team and influence critical thinking practices, verbal and nonverbal communications are what integrate the two skill sets. Without strong verbal and nonverbal communication skills, the students will struggle to communicate critical thoughts and work in a team. As is evident, interpersonal skills are interrelated and critical to the success of the predoctoral students.

Since there is a natural affinity in the group model for the development of interpersonal skills, the next step would be to develop a rubric to help the students and GPL measure improvement over time (Table S1). According to this study, the areas that are the most impacted by the model are critical thinking, teamwork, and both verbal and nonverbal listening skills. The students and GPLs could meet after completing a survey containing a rubric that measures these interpersonal skills. This would inform the student of the areas that the GPL will be assessing and the student will be self-assessing. These rubrics could be given to other supervising faculty as well. Another metric to assess skill development at a program level could be to provide patients with satisfaction surveys. These surveys and subsequent meetings would take place every 6 months during the time the student is in the clinic. These surveys would be used to rate dental students' interpersonal skills in the clinic, and in turn, used to measure interpersonal skills over time. Meetings between the GPL and student would be critical, as it would be the time the GPL 
could identify areas that need improvement and work on a development plan for the student. It would also be a time to recognize exceptional work. An overall grade would be given at the end of each semester by the GPL, which would be an accumulation of the rubrics given for each skill set over the course of the semester.

Based on the open-ended responses from the faculty members and feedback from the focus group, it seems that the challenge of limited instructional time can be addressed by introducing innovative methodologies and technologies. Innovative techniques can be applied to offer opportunities to the faculty members and students to further enhance interpersonal skills. Use of technologies in this space is a topic for further research to be discussed in-depth in a subsequent article.

There are limitations to note within this study. First, all the GPLs were from the same institution, which means that the findings may not be applicable to all schools and social desirability bias is at play. Second, the structure and definition of group practice may vary in different institutions. Third, the methodology used for this study allows for descriptive statistics, not comparative evidence. This results in perceived conclusions. Finally, the definition, meaning, and interpretation of different interpersonal skill attributes may vary.

Despite these limitations, this study's results demonstrate that under the proper circumstances, the group practice model naturally becomes a platform to enhance interpersonal skills for its students. With limited space to add content to a dental school's curriculum, the group practice model may be an ideal venue to improve methods of training dental students to further hone their skills and improve relationship with patients, colleagues, and coworkers.

\section{Conclusion}

The GPLs in the study identified the importance of the group practice model in enhancing interpersonal skills of predoctoral students. Among various interpersonal skills, the study suggested most impact on critical thinking, teamwork, and verbal and nonverbal communications, skills essential for a successful dentist. However, the research should be extended to other dental schools with similar clinical models for further validation of the results.

\section{Acknowledgment}

The surveys completed by the GPLs at the GSDM made this research and article possible.

\section{Disclosure}

The authors report no conflicts of interest in this work.

\section{References}

1. Gonzalez MA, Abu Kasim NH, Naimie Z. Soft skills and dental education. Eur J Dent Educ. 2013;17(2):73-82.

2. Shepherd T, Braham J, Elston C. Listening and Interpersonal Skills Review [last updated January 13, 2010]. Available from archive.learnhigher.ac.uk/resources/files/LIPS/literature_review.pdf. Accessed November 29, 2016.

3. Lievens F, Sackett PR. The validity of interpersonal skills assessment via situational judgment tests for predicting academic success and job performance. J Appl Psychol. 2012;97(2):460-468.

4. National Research Council (US) Committee on the Assessment of 21 st Century Skills. Assessing interpersonal skills. In: Assessing 21st Century Skills: Summary of a Workshop. Washington, DC: National Academies Press; 2011:3. Available from: https://www.ncbi.nlm.nih. gov/books/NBK84226/. Accessed November 29, 2016.

5. Barakat N. Interpersonal skills. Libyan J Med. 2007;2(3):152-153.

6. Gunderman RB, Brown BP. Teaching interpersonal and communication skills. Acad Radiol. 2012;19(12):1589-1590.

7. Hannah A, Millichamp CJ, Ayers KM. A communication skills course for undergraduate dental students. J Dental Educ. 2004; 68(9):970-977.

8. Rozier RG, Horowitz AM, Podschun G. Dentist-patient communication techniques used in the United States: the results of a national survey. $J$ Am Dent Assoc. 2011;142(5):518-530.

9. Branch WT Jr, Chou CL, Farber NJ, et al. Faculty development to enhance humanistic teaching and role modeling: a collaborative study at eight institutions. J Gen Intern Med. 2014;29(9):1250-1255.

10. Vujicic M, Israelson H, Antoon J, Kiesling R, Paumier T, Zust M. A profession in transition. $J$ Am Dent Assoc. 2014;145(2):118-121.

11. Ayers KM, Thomson WM, Rich AM, Newton JT. Gender differences in dentists' working practices and job satisfaction. $J$ Dent. 2008;36(5):343-350.

12. Orsini CA, Jerez OM. Establishing a good dentist-patient relationship: skills defined from the dental faculty perspective. J Dent Educ. 2014;78(10):1405-1415.

13. Walker MP, Duley SI, Beach MM, et al. Dental education economics: challenges and innovative strategies. J Dent Educ. 2008;72(12):1440-1449.

14. Wanchek T, Nicholson S, Vujicic M, Menezes A, Ziebert A. Educational debt and intended employment choice among dental school seniors. $J$ Am Dent Assoc. 2014;145(5):428-434.

15. Commission on Dental Accreditation. Accreditation [updated November 6, 2017; cited December 11, 2017]. Available at: http://www.ada.org/ en/coda/accreditation. Accessed November 29, 2016.

16. Association of American Medical Colleges. Core Entrustable Professional Activities for Entering Residency [2014]. Available from: https:// members.aamc.org/eweb/upload/Core\%20EPA\%20Faculty\%20and $\% 20$ Learner\%20Guide.pdf. Accessed November 29, 2016.

17. Ten Cate O. Nuts and bolts of entrustable professional activities. $J$ Grad Med Educ. 2013;5(1):157-158.

18. Englehardt-Nash D. "It takes teamwork." Dent Econ. 93(10). 


\section{Supplementary materials}

Figure SI Survey questions to be presented to the group practice leaders (subjects)

\begin{tabular}{|l|l|l|l|l|l|}
\hline $\begin{array}{l}\text { Question } \\
\text { What impact has the group practice model had on the following } \\
\text { areas: }\end{array}$ & $\begin{array}{l}\text { Strongly } \\
\text { impacts }\end{array}$ & Impacts & Neutral & $\begin{array}{l}\text { Does not } \\
\text { impact }\end{array}$ & $\begin{array}{l}\text { Strongly does } \\
\text { not impact }\end{array}$ \\
\hline Overall development of interpersonal skills & & & & & \\
\hline Verbal, nonverbal, and listening skills & & & & & \\
\hline Critical thinking & & & & & \\
\hline Negotiation skills & & & & & \\
\hline Collaboration & & & & & \\
\hline Assertiveness & & & & & \\
\hline Self-reflection & & & & & \\
\hline Teamwork & & & & & \\
\hline Leadership & & & & & \\
\hline
\end{tabular}

Please rank in order, which skill has the group practice model most influenced.

(One being the most influence and eight being the least influence)

\begin{tabular}{|l|l|}
\hline Skill & Order \\
\hline Verbal, nonverbal, and listening skills & \\
\hline Critical thinking skills & \\
\hline Negotiation skills & \\
\hline Collaboration & \\
\hline Assertiveness & \\
\hline Self-reflection & \\
\hline Teamwork & \\
\hline Leadership & \\
\hline
\end{tabular}

What else could be provided to the group practice model to impact interpersonal skills of predoctoral dental students?

Comments:

Demographic information of the participants

\begin{tabular}{|l|l|}
\hline Gender & \\
\hline Male & \\
\hline Female & \\
\hline
\end{tabular}

\begin{tabular}{|l|l|}
\hline Years since graduation from dental school & \\
\hline $0-10$ years & \\
\hline $11-20$ years & \\
\hline 21 plus years & \\
\hline
\end{tabular}


Table SI Interpersonal skills scoring rubric

\begin{tabular}{|c|c|c|c|c|c|}
\hline Interpersonal skill & 4 points & 3 points & 2 points & I point & $\begin{array}{l}\text { Improvement } \\
\text { (circle one) }\end{array}$ \\
\hline Communication skills & $\begin{array}{l}\text { Routinely communicates } \\
\text { effectively and } \\
\text { professionally. } \\
\text { Demonstrates active } \\
\text { listening skills. }\end{array}$ & $\begin{array}{l}\text { Mostly communicates } \\
\text { effectively and } \\
\text { professionally. } \\
\text { Demonstrates active } \\
\text { listening skills. }\end{array}$ & $\begin{array}{l}\text { Occasionally } \\
\text { communicates effectively } \\
\text { and professionally. } \\
\text { Demonstrates active } \\
\text { listening skills. }\end{array}$ & $\begin{array}{l}\text { Rarely communicates } \\
\text { effectively and } \\
\text { professionally. } \\
\text { Demonstrates active } \\
\text { listening skills. }\end{array}$ & $\begin{array}{l}\text { Improved. } \\
\text { Declined. } \\
\text { No change. }\end{array}$ \\
\hline Critical thinking & $\begin{array}{l}\text { Routinely able to } \\
\text { provide conflict } \\
\text { resolution and evaluate } \\
\text { outcome. }\end{array}$ & $\begin{array}{l}\text { Mostly able to provide } \\
\text { conflict resolution and } \\
\text { evaluate outcome. }\end{array}$ & $\begin{array}{l}\text { Occasionally able } \\
\text { to provide conflict } \\
\text { resolution and evaluate } \\
\text { outcome. }\end{array}$ & $\begin{array}{l}\text { Rarely able to provide } \\
\text { conflict resolution and } \\
\text { evaluate outcome. }\end{array}$ & $\begin{array}{l}\text { Improved. } \\
\text { Declined. } \\
\text { No change. }\end{array}$ \\
\hline Negotiation skills & $\begin{array}{l}\text { Routinely able to } \\
\text { intervene, support } \\
\text { discussion, and } \\
\text { compromise when } \\
\text { appropriate. }\end{array}$ & $\begin{array}{l}\text { Mostly able to intervene, } \\
\text { support discussion, } \\
\text { and compromise when } \\
\text { appropriate. }\end{array}$ & $\begin{array}{l}\text { Occasionally able to } \\
\text { intervene, support } \\
\text { discussion, and } \\
\text { compromise when } \\
\text { appropriate. }\end{array}$ & $\begin{array}{l}\text { Rarely able to } \\
\text { intervene, support } \\
\text { discussion, and } \\
\text { compromise when } \\
\text { appropriate. }\end{array}$ & $\begin{array}{l}\text { Improved. } \\
\text { Declined. } \\
\text { No change. }\end{array}$ \\
\hline Assertiveness & $\begin{array}{l}\text { Routinely confident and } \\
\text { decisive while remaining } \\
\text { respectful to others. }\end{array}$ & $\begin{array}{l}\text { Mostly confident and } \\
\text { decisive while remaining } \\
\text { respectful to others. }\end{array}$ & $\begin{array}{l}\text { Occasionally confident } \\
\text { and decisive while } \\
\text { remaining respectful to } \\
\text { others. }\end{array}$ & $\begin{array}{l}\text { Rarely confident } \\
\text { and decisive while } \\
\text { remaining respectful to } \\
\text { others. }\end{array}$ & $\begin{array}{l}\text { Improved. } \\
\text { Declined. } \\
\text { No change. }\end{array}$ \\
\hline Self-reflection & $\begin{array}{l}\text { Routinely understands } \\
\text { personal limits, assesses } \\
\text { work performed, and } \\
\text { self-corrects as needed. }\end{array}$ & $\begin{array}{l}\text { Mostly understands } \\
\text { personal limits, assesses } \\
\text { work performed, and } \\
\text { self-corrects as needed. }\end{array}$ & $\begin{array}{l}\text { Occasionally } \\
\text { understands personal } \\
\text { limits, assesses work } \\
\text { performed, and self- } \\
\text { corrects as needed. }\end{array}$ & $\begin{array}{l}\text { Rarely understands } \\
\text { personal limits, assesses } \\
\text { work performed, and } \\
\text { self-corrects as needed. }\end{array}$ & $\begin{array}{l}\text { Improved. } \\
\text { Declined. } \\
\text { No change. }\end{array}$ \\
\hline Team work & $\begin{array}{l}\text { Routinely able to } \\
\text { collaborate and can offer } \\
\text { varying perspectives. }\end{array}$ & $\begin{array}{l}\text { Mostly able to } \\
\text { collaborate and can offer } \\
\text { varying perspectives. }\end{array}$ & $\begin{array}{l}\text { Occasionally able to } \\
\text { collaborate and can offer } \\
\text { varying perspectives. }\end{array}$ & $\begin{array}{l}\text { Rarely able to } \\
\text { collaborate and } \\
\text { can offer varying } \\
\text { perspectives. }\end{array}$ & $\begin{array}{l}\text { Improved. } \\
\text { Declined. } \\
\text { No change. }\end{array}$ \\
\hline Leadership & $\begin{array}{l}\text { Routinely principled, } \\
\text { courteous, and } \\
\text { professional. Embodies } \\
\text { the core values of the } \\
\text { Dental School. }\end{array}$ & $\begin{array}{l}\text { Mostly principled, } \\
\text { courteous, and } \\
\text { professional. Embodies } \\
\text { the core values of the } \\
\text { Dental School. }\end{array}$ & $\begin{array}{l}\text { Occasionally principled, } \\
\text { courteous, and } \\
\text { professional. Embodies } \\
\text { the core values of the } \\
\text { Dental School. }\end{array}$ & $\begin{array}{l}\text { Rarely principled, } \\
\text { courteous, and } \\
\text { professional. Embodies } \\
\text { the core values of the } \\
\text { Dental School. }\end{array}$ & $\begin{array}{l}\text { Improved. } \\
\text { Declined. } \\
\text { No change. }\end{array}$ \\
\hline Comments & & & & & \\
\hline
\end{tabular}

\section{Publish your work in this journal}

The Journal of Healthcare Leadership is an international, peer-reviewed, open access journal focusing on leadership for the health profession. The journal is committed to the rapid publication of research focusing on but not limited to: Healthcare policy and law; Theoretical and practical aspects of healthcare delivery; Interactions between healthcare and society and evidence-based practices;
Dovepress

Interdisciplinary decision-making; Philosophical and ethical issues; Hazard management; Research and opinion for health leadership; Leadership assessment. The manuscript management system is completely online and includes a very quick and fair peer-review system. Visit http://www.dovepress.com/ testimonials.php to read real quotes from published authors. 